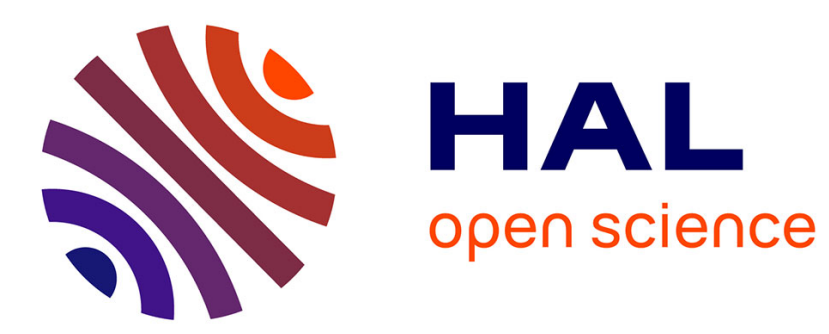

\title{
Monitoring diclofenac adsorption by organophilic alkylpyridinium bentonites
}

D. B. França, Pollyana Trigueiro, E.C. Silva Filho, M. G. Fonseca, M. Jaber

\section{To cite this version:}

D. B. França, Pollyana Trigueiro, E.C. Silva Filho, M. G. Fonseca, M. Jaber. Monitoring diclofenac adsorption by organophilic alkylpyridinium bentonites. Chemosphere, 2019, 242, pp.125109. 10.1016/j.chemosphere.2019.125109 . hal-02344483

\section{HAL Id: hal-02344483 https://hal.sorbonne-universite.fr/hal-02344483}

Submitted on 4 Nov 2019

HAL is a multi-disciplinary open access archive for the deposit and dissemination of scientific research documents, whether they are published or not. The documents may come from teaching and research institutions in France or abroad, or from public or private research centers.
L'archive ouverte pluridisciplinaire HAL, est destinée au dépôt et à la diffusion de documents scientifiques de niveau recherche, publiés ou non, émanant des établissements d'enseignement et de recherche français ou étrangers, des laboratoires publics ou privés. 


\section{Monitoring diclofenac adsorption by organophilic alkylpyridinium}

\section{bentonites} (1)

${ }^{a}$ Universidade Federal da Paraíba, Cidade Universitária, s/n - Castelo Branco III, 58051 085, João Pessoa - PB, Brazil.

${ }^{b}$ Núcleo de Pesquisa e Extensão - Laboratório de Combustíveis e Materiais (NPELACOM).

${ }^{c}$ Laboratório Interdisciplinar de Materiais Avançados (LIMAV), Centro de Tecnologia, UFPI, Teresina, Piaui, Brazil, 64064-260.

${ }^{d}$ Sorbonne Université, Laboratoire d'Archéologie Moléculaire et Structurale, CNRS UMR 8220, Tour 23, 3ème étage, couloir 23-33, BP 225, 4 place Jussieu, 75005 Paris, France.

7)

8

19

4 *Corresponding author: mgardennia@quimica.ufpb.br

25 Phone/fax $+55(83)$ 3216-7441 


\section{Abstract}

Organoclays have been applied as efficient adsorbents for pharmaceutical pollutants from aqueous solution. In this work, dodecylpyridinium chloride $\left(\mathrm{C}_{12} \mathrm{pyCl}\right)$ and hexadecylpyridinium chloride $\left(\mathrm{C}_{16} \mathrm{pyCl}\right)$ cationic surfactants were used for the preparation of organobentonites destined for diclofenac sodium (DFNa) adsorption, an anionic drug widely detected in wastewater. The organofunctionalization of the clay samples was performed under microwave irradiation at $50{ }^{\circ} \mathrm{C}$ for 5 min with surfactant amounts of $100 \%$ and $200 \%$ in relation to the cation exchange capacity (CEC) of the pristine bentonite. The amount of incorporated ammonium salts based on $\mathrm{CHN}$ elemental analysis was higher for all samples prepared with $200 \%$ of the CEC. The basal spacings of the organoclays ranged from 1.54$2.13 \mathrm{~nm}$, indicating the entrance of organic cations into the interlayer spacing of the clay samples, and the spacing depended on the size of the alkyl organic chain. The hydrophobic character of the organobentonites was verified by thermogravimetry and infrared spectroscopy (FTIR). The adsorption isotherms showed that the drug capacity adsorption was influenced by the amount of surfactant incorporated into the bentonite, the packing density and the arrangement of the surfactants in the interlayer spacing. Zeta potential measurements of the organobentonites and FTIR analysis after drug adsorption suggested that electrostatic and nonelectrostatic interactions contributed to the mechanism of adsorption.

Keywords: Organobentonite; microwave heating; adsorption; anti-inflammatory drug; diclofenac 


\section{Introduction}

The presence of pharmaceutical compounds in the environment has become a major concern, particularly due to the consequences related to long exposure, which are still unknown (Lonappan et al., 2016). Diclofenac (2- [2,6-dichlorophenylamino] phenylethanoic acid) is among the main drugs studied in recent years. Diclofenac is a nonsteroidal antiinflammatory drug often prescribed in human and veterinary medicine and used to reduce inflammation and pains (Acuña et al., 2015; He et al., 2017). As a consequence of its high production and consumption worldwide, both diclofenac and its metabolites have been detected in aquatic bodies in several countries at concentrations of $0.7-4400 \mathrm{ng} \mathrm{L}^{-1}$ in surface waters and up to $8.5 \mu \mathrm{g} \mathrm{L}^{-1}$ in wastewater (Lonappan et al., 2016; Scheurell et al., 2009); concentrations of its transformation products are in the range of 0.08 to $1.80 \mu \mathrm{g} \mathrm{L}^{-1}$ (Scheurell et al., 2009). In Brazil, diclofenac was also observed in water in the range of 3.3-785 ng L $\mathrm{L}^{-1}$ (Starling et al., 2019). Therefore, diclofenac is among the main drugs studied in recent years regarding its identification/detection in aquatic bodies (Biel-Maeso et al., 2018; Starling et al., 2019), removal/degradation (Maia et al., 2019; Mugunthan et al., 2018), and environmental impacts (Klaudia et al., 2019; Moreno-González et al., 2016; Oaks et al., 2004).

Both toxicity and bioaccumulation of diclofenac have been observed for various living aquatic organisms, even at low concentrations (Klaudia et al., 2019; Moreno-González et al., 2016), and diclofenac was identified as the cause of mortality and decline of the vulture population in Pakistan (Oaks et al., 2004). Some studies have observed that diclofenac metabolites can be generated through biotransformation in living organisms or through exposure to sunlight, and some of them are even more toxic than pure diclofenac (Bonnefille et al., 2018; Klaudia et al., 2019).

Due to the environmental problems, several diclofenac removal methods have been evaluated, such as coagulation, flocculation and activated sludge treatment (Carballa et al., 
2005; Vieno and Sillanpää, 2014); adsorption based on natural or synthetic materials (Andrew Lin et al., 2015; Maia et al., 2019); and degradation through advanced oxidative processes, such as ozonation (Beltrán et al., 2009), photo-Fenton (Pérez-Estrada et al., 2005) and photocatalysis (Mugunthan et al., 2018).

In this context, adsorption is highlighted because of the ease of operation and avoidance of subproducts. Organophilic clay minerals have been applied as efficient adsorbents for drug removal from aquatic bodies (Ghemit et al., 2019; Karaman et al., 2012; Maia et al., 2019; Martinez-Costa et al., 2018; Oliveira et al., 2017; Oliveira and Guégan, 2016; Sun et al., 2017a; Thanhmingliana, 2015). The performance of organophilic clays was attributed to a better compatibility with organic pollutants thanks to their hydrophobic nature and to the presence of new sites for adsorption (Oliveira and Guégan, 2016; Zhuang et al., 2019, 2018). Therefore, modified clays with surfactants containing an aromatic ring in their structure have been applied for the adsorption of different pollutants, such as phenolic compounds (Luo et al., 2015), aniline (Gu et al., 2014), bisphenol A (Yang et al., 2016), naphthalene and phenanthrene (Changchaivong and Khaodhiar, 2009). The mechanism of interaction involves both $\pi-\pi$ interactions between aromatic rings of the surfactant and the rings of the pollutant and other organic interactions (hydrogen bonding, London forces, etc), making these modified clays better adsorbents (Oliveira et al., 2017; Oliveira and Guégan, 2016). Indeed, hexadecylpyridinium chloride was used, commonly applied as an antibacterial agent widely in antiseptic solutions and some personal care products, as well as a preservative in pharmaceutical preparations and in the meat industry as a spray for the control of microbial growth (Herrera et al., 2004; Özdemir et al., 2013).

Furthermore, the adsorption of organic pollutants is improved when the incorporated amount of surfactant is higher than the cationic exchange capacity (CEC) of the clay mineral (Brito et al., 2018; Luo et al., 2018). 
In the present study, organoclays were obtained by the organofunctionalization of

100

101

102

103

104

105

106

107

108

109

110

111

112 bentonite, a mineral constituted predominantly by $\geq 50 \%$ smectite, most commonly montmorillonite (Mt). Mt is a 2:1 phyllosilicate with a general structure of $\left(\mathrm{M}^{\mathrm{x}+}, \mathrm{nH}_{2} \mathrm{O}\right)\left(\mathrm{Al}^{3+}{ }_{2-}\right.$ ${ }_{\mathrm{y}} \mathrm{Mg}^{2+}{ }_{\mathrm{y}} \mathrm{Si}^{4+}{ }_{4} \mathrm{O}_{10}(\mathrm{OH})_{2}$, where $\mathrm{Si}^{4+}$ ions are coordinated to four oxygens in tetrahedral sites and $\mathrm{Mg}^{2+} / \mathrm{Al}^{3+}$ ions are octahedrally coordinated to six oxygens. The hydrated interlayer cations $\mathrm{M}^{\mathrm{x}+}$ (commonly $\mathrm{Na}^{+}$or $\mathrm{Ca}^{2+}$ ) balance the negative layer charge due to the isomorphic substitution of $\mathrm{Mg}^{2+}$ for $\mathrm{Al}^{3+}$ in the octahedral sheet. These interlayer cations can be exchanged by organic cations in water solution, resulting in organophilic bentonite derivatives (Lagaly et al., 2013).

Therefore, in this case, organobentonites were synthesized through microwave (MW) heating in a very short time $(5 \mathrm{~min})$ by reaction with two alkylpyridinium surfactants that have aromatic rings in their structure. The influences of the chain length and composition of both molecules on the synthesis of organobentonites, and diclofenac adsorption on modified clay samples was evaluated. The synthetized samples were used for the first time for diclophenac adsorption. The tests of drug adsorption were conducted under different experimental conditions, and the influence of adsorbent dosage, $\mathrm{pH}$, time and initial diclofenac concentration were investigated. New insights in the mechanism of drug/solid adsorption were also suggested based on characterization of the adsorbents after drug adsorption.

\section{Experimental}

\subsection{Materials}

A sodium bentonite sample (BentNa), CEC $74.64 \mathrm{cmol}(+) / \mathrm{kg}$, was supplied by Bentonise Bentonita Company, Brazil. The chemical composition of the bentonite was as follows: $\mathrm{SiO}_{2}(52.98 \%), \mathrm{Al}_{2} \mathrm{O}_{3}(18.35 \%), \mathrm{Fe}_{2} \mathrm{O}_{3}$ (3.96\%), $\mathrm{TiO}_{2}(0.18 \%), \mathrm{CaO}(0.01 \%), \mathrm{MgO}$ 
(2.47\%), $\mathrm{Na}_{2} \mathrm{O}(2.56 \%), \mathrm{K}_{2} \mathrm{O}(0.22 \%)$ and fire loss $18.59 \%$ (Cavalcanti et al., 2019). 1-

Dodecylpyridinium chloride hydrate $\left(\mathrm{C}_{12} \mathrm{pyCl}\right)$ and hexadecylpyridinium chloride

125

126

127

128

129

monohydrate $\left(\mathrm{C}_{16} \mathrm{pyCl}\right)$ with purity grades of $98 \%$ and $99 \%$, respectively, were supplied by

Sigma-Aldrich and used as received. Diclofenac sodium salt (CAS number 15307-79-6, MM $=318.13 \mathrm{~g} \mathrm{~mol}^{-1}$ and $\left.\mathrm{pKa} 4.1\right)$ was purchased from Sigma-Aldrich.

\subsection{Preparation of the alkylpyridinium bentonites}

Organobentonites were synthesized based on a previous procedure (Brito et al., 2018). Initially, two solutions of the salts were prepared in concentrations corresponding to 100 and $200 \%$ of the CEC of the bentonite. A sample of $4.0 \mathrm{~g}$ of BentNa was suspended in $100 \mathrm{~mL}$ of each surfactant solution in a Teflon vessel reactor and heated in a microwave reactor (IS-TEC MW reactor model RMW-1, Brazil, with a power of $1100 \mathrm{~W}$ and $2.45 \mathrm{GHz}$ ) for $5 \mathrm{~min}$ at 50 ${ }^{\circ} \mathrm{C}$. The obtained solids were recovered by centrifugation at $10000 \mathrm{rpm}$, washed with distilled water until testing negative for chlorite with $0.01 \mathrm{~mol} \mathrm{~L}^{-1} \mathrm{AgNO}_{3}$ and dried in an oven for at least $24 \mathrm{~h}$ at $50{ }^{\circ} \mathrm{C}$.

\subsection{Diclofenac sorption}

The test of diclofenac adsorption followed a previous method (Brito et al., 2018; França et al., 2019), by which the influences of the medium $\mathrm{pH}(6.0-10.0)$, dosage of the solid (25-400 mg), time $(0.5-120 \mathrm{~min})$ and drug initial concentration $\left(1-500 \mathrm{mg} \mathrm{L}^{-1}\right)$ were evaluated.

Batch tests were performed at $30{ }^{\circ} \mathrm{C}$ by using samples of organobentonites dispersed in $20 \mathrm{~mL}$ of diclofenac solution. This temperature is the medium temperature found for Brazilian aquatic bodies. After each test, the solids were recovered by centrifugation, and the diclofenac concentrations were monitored by UV-Vis molecular spectrometry (Shimadzu 
spectrometer model TCC-240 240) at $276 \mathrm{~nm}$ (Ghemit et al., 2019). The amount of adsorbed drug (q) was calculated as established in Eq. 1:

$$
q=\frac{\left(C_{i}-C_{e}\right) V}{m}
$$

where $C_{i}$ and $C_{e}$ are the drug concentrations before and after adsorption $\left(\mathrm{mg} \mathrm{L} \mathrm{L}^{-1}\right)$, respectively, $V$ is the total volume of drug solution (L) and $m$ is the mass of the solid (g).

To investigate $\mathrm{pH}, 50 \mathrm{mg}$ of solids was reacted with $20 \mathrm{~mL}$ of $100 \mathrm{mg} \mathrm{L}^{-1}$ diclofenac solution for $24 \mathrm{~h}$. The $\mathrm{pH}$ was adjusted with $0.05 \mathrm{~mol} \mathrm{~L}^{-1} \mathrm{NaOH}$ or $\mathrm{HNO}_{3}$ solutions.

Tests for the dosage of solids were monitored at optimum $\mathrm{pH}$ under the same conditions described.

Tests for different times of interaction were conducted with the fixed mass obtained in the solid dosage tests and at optimum $\mathrm{pH}$ for times in the range of 0.5-120 min.

Finally, the initial diclofenac concentrations were evaluated in the range of 1-500 mg $\mathrm{L}^{-1}$ at the optimized $\mathrm{pH}$, dosage of solids and time of contact.

All experiments were performed in triplicate.

\subsection{Kinetic and equilibrium models}

The experimental data were adjusted to fit the following kinetic models: pseudo-firstorder (Lagergren, 1898), pseudo-second-order (Ho and McKay, 1999) and simplified Elovich equation (Chien and Clayton, 1984), assuming $\alpha \beta t \gg>1$, (see Eqs. 1 to 3 in Supplementary Material SI1).

The equilibrium isotherms were analyzed with the Langmuir (Langmuir, 1918), Freundlich (Freundlich, 1906) and Temkin (Temkin and Pyzhev, 1940) models (see Eqs. 4-6 in Supplementary Material SI1). 

equation models were best suited to describe the experimental data (Lima et al., 2015).

$$
S D=\sqrt{\frac{1}{n_{p}-p} \sum_{i}^{n}\left(q_{i, \text { exp }}-q_{i, \text { model }}\right)^{2}}
$$
the number of parameters of the fitted model.

\subsection{Characterizations}

X-ray diffraction (XRD) analyses were conducted on a Shimadzu XD3A model diffractometer with $\mathrm{CuK \alpha}$ radiation and a fixed power source (40 kV and $30 \mathrm{~mA})$. FTIR spectra were recorded in the $4000-400 \mathrm{~cm}^{-1}$ region by a Shimadzu IR Prestige- 21 model; the samples were dispersed in $\mathrm{KBr}$ pellets, and a resolution of $4 \mathrm{~cm}^{-1}$ and accumulation of 20 scans were used for each run. Thermogravimetry data for the solids were obtained using an SDT Q600 V20.9 Build 20 thermal analyzer with a heating rate of $10{ }^{\circ} \mathrm{C} \mathrm{min}^{-1}$ under $100 \mathrm{~mL}$ $\min ^{-1}$ of argon flow in the range of 30 to $900{ }^{\circ} \mathrm{C}$. $\mathrm{CHN}$ elemental analysis was obtained by using a Perkin-Elmer PE-2400 microelemental analyzer. Chloride was analyzed by titration: samples of $100 \mathrm{mg}$ in triplicate was suspended in $0.01 \mathrm{~mol} \mathrm{~L}^{-1} \mathrm{NaNO}_{3}$ for $24 \mathrm{~h}$ at $25{ }^{\circ} \mathrm{C}$. The dispersions were centrifuged and the procedure was repeated 3 times to ensure the exchange of $\mathrm{Cl}^{-}$by $\mathrm{NO}_{3}{ }^{-}$. After centrifugation, aliquots of $10 \mathrm{~mL}$ of supernatant were titrated with

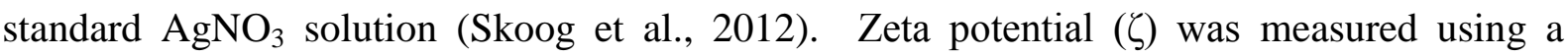
of the solutions was adjusted with $0.100 \mathrm{~mol} \mathrm{~L}^{-1} \mathrm{NaOH}$ or $0.500 \mathrm{~mol} \mathrm{~L}^{-1} \mathrm{HNO}_{3}$. 


\section{Results and discussion}

193

194

195

196

197

198

199

200

201

202

203

204

205

206

207

208

209

210

211

212

213

214

215

\subsection{X-ray diffraction}

The XRD pattern of BentNa (Figure SM1a) showed smectite with sodium montmorillonite (Mt) as the predominant phase and impurities of quartz (Q) and muscovite (M), in agreement with ICDD cards 00.029.1498, 00.058.2036 and 01.070.8055 and previous studies (Cavalcanti et al., 2019; Queiroga et al., 2019). Characteristic reflections of Mt at $2 \theta=$ $7.37^{\circ}$ suggested a basal spacing $\left(\mathrm{d}_{001}\right)$ of $1.12 \mathrm{~nm}$, as further indicated by additional reflections at $2 \theta$ values of $19.6^{\circ}, 28.3^{\circ}, 35.0^{\circ}$ and $61.8^{\circ}$.

The intercalation of alkylpyridinium cations was confirmed by the increase in basal spacings to $1.56,1.74,1.66$ and $2.13 \mathrm{~nm}$ for Bent- $\mathrm{C}_{12}$ py-100\%, Bent- $\mathrm{C}_{16}$ py-100\%, Bent$\mathrm{C}_{12}$ py-200\% and Bent- $\mathrm{C}_{16}-\mathrm{py} 200 \%$ (Figure SM1), respectively. The results indicated that higher values were observed for solids prepared with $200 \%$ of the CEC and a longer organic chain of the salt (Changchaivong and Khaodhiar, 2009; Greenland and Quirk, 1962; MuñozShugulí et al., 2019).

Studies have established that the size of the organic chain and the intercalated amount determine the arrangement of surfactants in the interlayer spacing. For example, $\mathrm{C}_{16} \mathrm{py}^{+}$ monolayer $\left(\mathrm{d}_{001}=1.32 \sim 1.47 \mathrm{~nm}\right)$, bilayer $\left(\mathrm{d}_{001}=1.68 \sim 1.78 \mathrm{~nm}\right)$ and pseudotrilayer $\left(\mathrm{d}_{001}=\right.$ 2.14 2.20 nm) arrangements in the gallery spacing of montmorillonite have been proposed (Meleshyn and Bunnenberg, 2006). Based on the size of the surfactant molecules and the final basal spacings (Chen et al., 2005; Luo et al., 2018), monolayer arrangement occurred for Bent- $\mathrm{C}_{12}$ py-100\%, bilayer arrangement occurred for Bent- $\mathrm{C}_{12}$ py-200\% and Bent- $\mathrm{C}_{16}$ py$100 \%$, and pseudotrilayer arrangement occurred for Bent- $\mathrm{C}_{16} \mathrm{py}-200 \%$, as illustrated in Figure SM2. 
The XRD results were compared with previous studies that considered the synthesis of organobentonites by using conventional and microwave heating with the same proportion of surfactant adopted in the present work (Table SM1). The obtained values for Bent- $\mathrm{C}_{16}$ py are close to those obtained by (Schampera and Dultz, 2009) and Muñoz-Shugulí et al. (2019) using conventional heating at times of 20 and $1 \mathrm{~h}$ at $60{ }^{\circ} \mathrm{C}$, respectively. However, divergent values were also observed and were associated with the different CECs of the pristine bentonites used (He et al., 2014) different conditions of synthesis. Therefore, the studies showed that aspects such as washing and drying (Luo et al., 2016) and the nature of the interlayer cations (Volzone et al., 2002) can influence the final basal spacing and the amount of intercalated surfactant.

\subsection{CHNCl elemental analysis}

The amount of incorporated surfactant in the bentonite was determined based on $\mathrm{C}$ and $\mathrm{N}$ elemental analysis (Table 1$)$; the values were close to the CEC $(\sim 90 \%$ of the initial salt concentration) for Bent- $\mathrm{C}_{12} \mathrm{py}-100 \%$ and Bent- $\mathrm{C}_{16} \mathrm{py}-100 \%$ and were near that for montmorillonites modified with $\mathrm{C}_{16} \mathrm{py}^{+}$using $100 \%$ of the $\mathrm{CEC}$ by conventional heating (Schampera and Dultz, 2009).

For the organobentonites obtained using $200 \%$ of the CEC of BentNa, only Bent$\mathrm{C}_{16}$ py-200\% exhibited a value higher than the CEC (112.4\%), while $\mathrm{C}_{12}$ py-200\% exhibited a value of $93.3 \%$. The excess of surfactant in Bent- $\mathrm{C}_{16} \mathrm{py}-200 \%$ was incorporated as the ion pair $\mathrm{C}_{16} \mathrm{pyCl}$ through hydrophobic interactions between the alkyl tails of the organic chain (Luo et al., 2018; Meleshyn and Bunnenberg, 2006), and was further verified by the presence of the chloride in the organoclays (Table 1). $\mathrm{No}^{-}$ions were detected in other organobentonites (Bent- $\mathrm{C}_{12}$ py-100\%, Bent- $\mathrm{C}_{16}$ py-100\% and Bent- $\mathrm{C}_{12}$ py-200\%). 
The better affinity of bentonite for surfactants with longer organic chains was related

242 to an increase in the contribution of Van der Waals interactions and a decrease in the

243 hydration enthalpy of the organic salt, favoring intercalation (Teppen and Aggarwal, 2007).

This result suggested that the packing densities of the groups in the solids can be

245 influenced by the amount of intercalated molecules.

\subsection{Infrared spectroscopy}

Infrared spectra were used to monitor the organofunctionalization of the bentonite; therefore, the spectra of the pristine and modified solids are shown in Figure SM3. For sodium bentonite, typical bands were detected at $3632 \mathrm{~cm}^{-1}$ and $3440 \mathrm{~cm}^{-1}$, assigned to the hydroxyl stretching of structural $\mathrm{M}-\mathrm{OH}\left(\mathrm{M}=\mathrm{Al}^{3+}, \mathrm{Mg}^{2+}\right.$ or $\left.\mathrm{Fe}^{3+}\right)$ and silanol. The bending of water molecules was also observed at $1638 \mathrm{~cm}^{-1}$ (Slaný et al., 2019).

For the region below $1200 \mathrm{~cm}^{-1}$, bands at 1115 and $1042 \mathrm{~cm}^{-1}$ were related to Si-O stretching, and bands at 915-847 $\mathrm{cm}^{-1}$ were due to $\mathrm{AlMOH}$ deformation $(\mathrm{M}=\mathrm{Al}, \mathrm{Fe}$ or $\mathrm{Mg})$ (Slaný et al., 2019). The presence of quartz impurities was confirmed by the Si-O deformation at $798 \mathrm{~cm}^{-1}$. Other bands at 620,519 and $465 \mathrm{~cm}^{-1}$ were assigned to Al-O/Si-O, Al-O-Si and Si-O-Si deformations, respectively, and are characteristic of montmorillonite (Slaný et al., 259 2019).

The intercalation of the surfactants in the clay minerals was accompanied by the appearance of new bands in the range of $3136-3096 \mathrm{~cm}^{-1}$, attributed to the aromatic $\mathrm{CH}$ stretching of pyridine rings, and from $2928-2851 \mathrm{~cm}^{-1}$, related to $\mathrm{CH}_{2}$ antisymmetric and symmetrical stretching vibrations (Lin-Vien et al., 1991; Luo et al., 2018). The location of the $v_{\mathrm{as}}\left(\mathrm{CH}_{2}\right)$ band at wavelengths higher than those of free surfactants (Table SM2) suggests the 
existence of structures with a disordered arrangement of organic cations (gauche conformers) in the interlayer region of the montmorillonite (Chen et al., 2005; Slaný et al., 2019).

The spectra also exhibited a low-intensity band at $1502 \mathrm{~cm}^{-1}$ associated with $\mathrm{C}=\mathrm{C}$ vibrations of aromatic rings, bands at 1486 and $1469 \mathrm{~cm}^{-1}$, associated with $\mathrm{CH}_{3}$ and $\mathrm{CH}_{2}$ deformations, respectively and a band at $729 \mathrm{~cm}^{-1}$, related to $\left(\mathrm{CH}_{2}\right)_{\mathrm{n}}$ in-phase rocking, characteristic of alkyl chains of surfactants (Lin-Vien et al., 1991; Slaný et al., 2019). The absorptions at 777 and $679 \mathrm{~cm}^{-1}$ were assigned to deformation of the pyridine ring (Lin-Vien et al., 1991).

\subsection{Thermogravimetry}

Thermogravimetry is a useful tool to quantify the amount of organic content in a solid but is also associated with other techniques, such as XRD and FTIR, to characterize how surfactants are confined in the interlayer region (Chen et al., 2005). TG curves (Figure SM4) and the associated mass losses are summarized in Table SM3.

The TG curve of pristine bentonite exhibited two steps of mass loss, the first step at $30-200{ }^{\circ} \mathrm{C}$, attributed to the elimination of the interlayer water and water adsorbed on the surface, and the second from $200-900{ }^{\circ} \mathrm{C}$, associated with the condensation of structural $\mathrm{OH}$ (Muñoz-Shugulí et al., 2019).

The organobentonites showed four and five events of mass loss. For all samples, the first event associated with the elimination of water was $\leq 1.2 \%$, suggesting the hydrophobic nature of the organoclays (Muñoz-Shugulí et al., 2019). Additionally, the sum of mass losses of the other events was higher than in the pristine clay and are associated to an exothermal event (Heat flow not presented), which was an indication of the presence of organic moieties in the solids. 
The initial temperature associated with the degradation of the organic part decreased as the incorporated amount of surfactant increased and was observed at 182, 175, 174 and 118 ${ }^{\circ} \mathrm{C}$ for the Bent-C12py-100\%, Bent-C16py-100\% Bent-C12py-200\% and Bent-C16py-200\% solids, respectively; this degradation finished at $513-520{ }^{\circ} \mathrm{C}$; therefore, the number of decomposition events exhibited within this range depended on the types of interactions (Chen et al., 2005; Muñoz-Shugulí et al., 2019).

Meleshyn and Bunnenberg, (2006) suggested that a lower temperature for the exit of surfactants occurs due to the different arrangements of organic chains in the interlayer spacing of clay samples and is an indication of weaker interactions (lower energy) between the organic cations and the mineral surface. In other words, as the organic cation content increases, the configurations change from monolayer and bilayer to pseudotrilayer, in accordance with the observed results.

Above $520{ }^{\circ} \mathrm{C}$, mass loss was attributed to dehydroxylation (Luo et al., 2018; MuñozShugulí et al., 2019).

\subsection{Zeta potential}

Zeta potential measurements (Figure SM5) suggested that the point of zero charge $\left(\mathrm{pH}_{\mathrm{PZC}}\right)$ occurred at $\mathrm{pH} 3.4,2.5,4.1$ and 8.1 for Bent- $\mathrm{C}_{12}-100 \%$, Bent- $\mathrm{C}_{16^{-}}-100 \%$, Bent- $\mathrm{C}_{12^{-}}$ $200 \%$ and Bent- $\mathrm{C}_{16}-200 \%$, respectively. BentNa is negatively charged in all $\mathrm{pH}$ ranges. The modification of clay minerals with cationic surfactants promotes a total or partial variation in surface charge, depending on the amount of organic cations incorporated (Brito et al., 2018; Schampera and Dultz, 2009). Therefore, the values of $\mathrm{pH}_{\mathrm{PZC}}$ observed for Bent- $\mathrm{C}_{12}-100 \%$, Bent- $\mathrm{C}_{16}-100 \%$ and Bent- $\mathrm{C}_{12}-200 \%$ are probably related to the low amount of surfactant incorporated ( $~ 90 \%$ of the CEC), while the higher value of $\mathrm{pH}_{\mathrm{PZC}}$ for Bent- $\mathrm{C}_{16}-200 \%$ is 
consistent with the excess surfactant adsorbed probably on the basal surface of the bentonite sample, as indicated by the $\mathrm{CHNCl}$ and thermogravimetry results.

\subsection{Adsorption of diclofenac on the solids}

\subsubsection{Influence of $\mathrm{pH}$}

The effect of $\mathrm{pH}$ on the adsorption process has often been evaluated according to the different behaviors presented by drugs and solids in aqueous media (Ghemit et al., 2019; Oliveira et al., 2017). This parameter was analyzed considering the speciation of the diclofenac molecule at different $\mathrm{pH}$ values (Figure SM6i) and zeta potential measurements $(\zeta)$ (Figure SM5). The results showed that the adsorption depended slightly on the $\mathrm{pH}$ (Figure SM6ii); the maximum values were $12.87,18.19,25.30$ and $39.40 \mathrm{mg} \mathrm{g}^{-1}$ for Bent-C $\mathrm{C}_{12}-100 \%$, Bent- $\mathrm{C}_{16}-100 \%$, Bent- $\mathrm{C}_{12}-200 \%$ and Bent- $\mathrm{C}_{16}-200 \%$, respectively, at $\mathrm{pH} 6.0$ and were better than those at $\mathrm{pH} 8$ and 10.

Based on the $\mathrm{pKa}$ (4.1) of diclofenac, at $\mathrm{pH} \geq 6$, the anionic form dominates, and the decreased adsorption with increased $\mathrm{pH}(6-10)$ for Bent- $\mathrm{C}_{12}-100 \%$, Bent- $\mathrm{C}_{16}-100 \%$ and Bent$\mathrm{C}_{12}-200 \%$ can be associated with the repulsion between deprotonated diclofenac and organobentonites (Luo et al., 2015), considering the $\mathrm{pH}_{\mathrm{PZC}}$ value; at $\mathrm{pH}<\mathrm{pH}_{\mathrm{PZC}}$, the surface is positively charged, and the surface is negatively charged for $\mathrm{pH}$ values above the $\mathrm{pH}_{\mathrm{PZC}}$. These results suggested that non-electrostatic interactions contributed to the mechanism of adsorption.

\subsubsection{Dosage of the adsorbent}

The dosage of the adsorbent (Figure SM7) is important for establishing the best adsorption efficiency of the drug from solution. The adsorption percentages increase 
gradually with increased organobentonite mass due to the increase of interaction sites amount (Brito et al., 2018; Ghemit et al., 2019).

The best performance was observed for $300,200,150$ and $50 \mathrm{mg}$ of $\mathrm{Bent}_{-} \mathrm{C}_{12}-100 \%$, Bent- $\mathrm{C}_{16}-100 \%$, Bent- $\mathrm{C}_{12}-200 \%$ and Bent- $\mathrm{C}_{16}-200 \%$, respectively and these dosages were associated with adsorption efficiencies of 88.3, 97.1, 93.5 and 99.5\%. The adsorbed amounts per gram of adsorbent (q) were $5.9 \mathrm{mg} \mathrm{g}^{-1}$ for Bent- $\mathrm{C}_{12}$ py-100\%, $9.3 \mathrm{mg} \mathrm{g}^{-1}$ for Bent- $\mathrm{C}_{16}$ py$100 \%$, $13.0 \mathrm{mg} \mathrm{g}^{-1}$ for Bent- $\mathrm{C}_{12}$ py-200\% and $38.7 \mathrm{mg} \mathrm{g}^{-1}$ para Bent- $\mathrm{C}_{16}$ py-200\% (Figure SM7ii).

\subsubsection{Kinetic studies}

Adsorption kinetic studies of diclofenac (Figure SM8) were carried out using the masses corresponding to the maximum percentages of diclofenac adsorption obtained in the evaluation of the adsorbent dosage effect at $\mathrm{pH}$ 6.0. The isotherms showed rapid adsorption of the drug by the organophilic clays at 60 and 10 min for the solids obtained with $100 \%$ and $200 \%$ of the CEC, respectively. These results were close to those observed for other organophilic clays used for diclofenac adsorption (Ghemit et al., 2019; Sun et al., 2017a).

The adsorption kinetics were analyzed by nonlinear regression of the isotherms to the pseudo-first-order, pseudo-second-order and Elovich models, whose parameters are summarized in Table 2 . In addition to $\mathrm{R}^{2}$, the fit of the isotherms to the models was also evaluated using the standard deviation (SD) (Lima et al., 2015), which showed a better fit to the Elovich equation for Bent- $\mathrm{C}_{12} \mathrm{py}-100 \%$ and Bent- $\mathrm{C}_{16} \mathrm{py}-100 \%$ and a better fit to the pseudo-second-order model for Bent- $\mathrm{C}_{12}$ py-200\% and Bent- $\mathrm{C}_{16}$ py-200\%. The Elovich model describes the process as chemisorption and considers the heterogeneity of the surface of the adsorbent (Lima et al., 2015). 


\subsubsection{Adsorption isotherms}

The equilibrium isotherms were evaluated at 1-500 $\mathrm{mg} \mathrm{L}^{-1}$ diclofenac (Figure 1), $\mathrm{pH} 6$ and $60 \mathrm{~min}$. The isotherms for the organobentonites initially showed an increase in adsorbed amount (qe) with increased drug concentration, reaching almost constant values at initial concentrations $(\mathrm{Ci})$ of $350 \mathrm{mg} \mathrm{L}^{-1}$ for Bent- $\mathrm{C}_{16} \mathrm{py}-100 \%$ and Bent- $\mathrm{C}_{12}$ py-200\%, $300 \mathrm{mg} \mathrm{L}^{-1}$ for Bent- $\mathrm{C}_{16} \mathrm{py}-200 \%$ and $450 \mathrm{mg} \mathrm{L}^{-1}$ for Bent-C ${ }_{12} \mathrm{py}-100 \%$.

The maximum adsorption capacities $\left(\mathrm{q}_{\max }\right)$ were $13.02,19.30,25.50$ and $91.13 \mathrm{mg} \mathrm{g}^{-1}$ on Bent- $\mathrm{C}_{12}$ py-100\%, Bent- $\mathrm{C}_{16}$ py-100\%, Bent- $\mathrm{C}_{12}$ py-200\% and Bent-C ${ }_{16}$ py-200\%, respectively. The result for pristine bentonite was less than $5 \%$ of the reported values $(<5 \mathrm{mg}$ $\mathrm{g}^{-1}$ ) under the same conditions. These results were also compared with the diclofenac adsorption capacity on other organoclays samples obtained from conventional procedure at time of 15-72 h (Table SM4), and illustrated the good performance of the organobentonites obtained in this study in only $5 \mathrm{~min}$ by microwave irradiation. Long time reactions is a limitation for use of organoclays industrial scale (Yapar, 2009), however, the use of microwave irradiation behaved as good alternative for rapid and reproductive preparation of modified clay minerals.

Beyond the low-cost and good efficiency of the organobentonites, the choice of adsorbent depends of other factors such biocompatibility with the ecosystem and their regeneration and recycle (Biswas et al., 2019; Momina et al., 2018), that were not studied in this present case.

Some organoclays exhibited high toxicity (Sarkar et al., 2013; Witthuhn et al., 2005) while others did not showed any toxicity for the original community of soil microorganisms responsible for biodegradation (Abbate et al., 2013), therefore, the toxicity of alkylpyridium bentonites remains still unknown. The antibacterial activities of hexadecylpyridinium-montmorillonites was verified only against some bacteria responsible for infections in humans and animals and food 
contamination (Herrera et al., 2000; Malachová et al., 2009; Özdemir et al., 2013), and when added to the diet of weaned pigs was proposed as an alternative to antibiotic chlortetracycline for improving growth performance, mucosal architecture and modifying intestinal microflora (Ke et al., 2014). Moreover, some studied observed that these solids can be used as precursor to obtain new materials such as porous clay heterostructures (Zhu et al., 2005) or carbon-clay composites (Jović-Jovičić et al., 2019).

Comparing the results for solids modified with the same surfactant, better adsorption was observed for adsorbents with a higher organic content and basal spacing, for example organobentonite prepared with 100 and $200 \%$ of the CEC. Similar results were observed in previous studies for organobentonites prepared with hexadecyltrimethylammonium (Ghemit et al., 2019; Sun et al., 2017a).

In addition, the nature of the surfactant, packing density, amount incorporated and organization of the organic cations in the interlayer region can influence drug adsorption in aqueous media (Oliveira et al., 2017; Oliveira and Guégan, 2016). Organic pollutant adsorption on organophilic pyridinium montmorillonites is dependent on these cited effects (Chen et al., 2005; Gu et al., 2014; Luo et al., 2015), as has also been observed for inorganic pollutants (Luo et al., 2017). The cited studies demonstrate that the different characteristics of organoclays influence their affinity for pollutants and, in some cases, their interaction mechanisms.

In this present case, the obtained $\mathrm{q}_{\mathrm{e}}$ values for diclofenac adsorption on Bent- $\mathrm{C}_{12}$ py$100 \%$, Bent- $\mathrm{C}_{16} \mathrm{py}-100 \%$ and Bent- $\mathrm{C}_{12}$ py-100\% were also influenced by the packing density and the organization of alkylpyridinium cations inside the interlayer spacing since these adsorbents presented lower amounts of incorporated surfactants (close to the CEC) but different $\mathrm{d}_{001}$ and cation sizes. 

adsorption models, and the parameters obtained are summarized in Table 3. From the values

414

\subsubsection{Characterization of the drug/clay mineral hybrids}

\subsubsection{X-ray diffraction}

XRD patterns of the drug/clay mineral hybrids (Figure 2) obtained with 10, 100 and $500 \mathrm{mg} \mathrm{L}^{-1}$ of initial drug concentrations did not present alterations in the basal spacing, as observed in the literature for organophilic montmorillonites (Oliveira et al., 2017; Oliveira and Guégan, 2016; Sun et al., 2017a).

The adsorption of a drug in the interlayer region of a clay mineral can drive the rearrangement of the surfactant molecules without changes in the value of the basal spacing (Meleshyn and Bunnenberg, 2006; Oliveira et al., 2017; Oliveira and Guégan, 2016; Sun et al., 2017a). For the sample Bent- $\mathrm{C}_{12}$ py-200\% $\left(\mathrm{d}_{001}=1.66 \mathrm{~nm}\right)$, the packaging density was higher than that for Bent- $\mathrm{C}_{12}$ py-100\% $\left(\mathrm{d}_{001}=1.56 \mathrm{~nm}\right)$. Consequently, the entrance of the drug would be more difficult for Bent- $\mathrm{C}_{12}$ py-200\%, however the adsorption was higher for this sample. It more reasonable that the drug did not access more internal adsorption sites.

For Bent- $\mathrm{C}_{16} \mathrm{py}-200 \%$, the behavior was different once the basal spacing was $2.13 \mathrm{~nm}$, the amount of organic salt in the solid was higher than the CEC $\left(0.84 \mathrm{mmol} \mathrm{g}^{-1}\right)$ associated 
with the presence of the $\mathrm{C}_{16} \mathrm{pyCl}$ ionic pair. Therefore, the presence of chloride in the equilibrium solution after drug adsorption was a strong indication of another mechanism for adsorption, such as anion exchange between the $\mathrm{Cl}^{-}$ions and anionic drug. Similar results have also been described previously in perchlorate adsorption (Chitrakar et al., 2012; Luo et al., 2016). The literature shows that $\mathrm{Cl}^{-}$ions in $\mathrm{C}_{16} \mathrm{py}^{+}$-modified montmorillonite were located near the mid plane of the interlayer space (Meleshyn and Bunnenberg, 2006) and are therefore accessible adsorption sites for anionic species, such as diclofenac.

\subsubsection{Infrared spectroscopy}

For better analysis of the results, the infrared spectra of the free drug and drug/solid hybrids prepared at 10,100 and $500 \mathrm{mg} \mathrm{L}^{-1}$ diclofenac were divided into three regions, (Figures 3 and SM9). Therefore, infrared spectra in the region of $4000-2750 \mathrm{~cm}^{-1}$ showed diclofenac bands at 3388 and $2357 \mathrm{~cm}^{-1}$ assigned to free and bound N-H stretching, respectively, the latter through intramolecular hydrogen bonds $\left(\mathrm{N}-\mathrm{H}^{\cdots} \mathrm{O} \mathrm{O}\right)$ (Kovala-Demertzi et al., 1993; Lin-Vien et al., 1991). The bands at 3080 and $3036 \mathrm{~cm}^{-1}$ were attributed to v(C$\mathrm{H})_{\text {aromatic }}$, and those at 2971 and $2897 \mathrm{~cm}^{-1}$ were due antisymmetric and symmetric aliphatic $\mathrm{CH}_{2}$ stretching (Lin-Vien et al., 1991). For the drug/Bent-C $16-200 \%$ hybrid, the initial band of $\mathrm{OH}$ stretching of water at $3410 \mathrm{~cm}^{-1}$ was shifted to $3430-3422 \mathrm{~cm}^{-1}$ for solids with $3.71 \mathrm{mg} \mathrm{g}^{-1}$ $\left(\mathrm{C}_{\mathrm{i}}=10 \mathrm{mg} \mathrm{L}^{-1}\right)$ and $91.13 \mathrm{mg} \mathrm{g}^{-1}\left(\mathrm{C}_{\mathrm{i}}=500 \mathrm{mg} \mathrm{L}^{-1}\right)$. For the other solids with diclofenac, no alteration was observed in this region.

For region $2\left(1750-1250 \mathrm{~cm}^{-1}\right)$, diclofenac presents typical bands associated with aromatic ring stretching at 1603 and $1556 \mathrm{~cm}^{-1}$, a band at 1507 and $1500 \mathrm{~cm}^{-1}$ assigned to C$\mathrm{N}-\mathrm{H}$ bending of the secondary amine and C-H rock of aromatic rings, band at $1468 \mathrm{~cm}^{-1}$ due to $\mathrm{C}-\mathrm{N}$ stretching and $\mathrm{C}-\mathrm{H}$ rock (aromatic ring), and bands at 1452 and $1305 \mathrm{~cm}^{-1}$ attributed to 
$461 \mathrm{CH}_{2}$ bending (Iliescu et al., 2004; Lin-Vien et al., 1991). The samples with adsorbed diclofenac showed broader bands of aromatic ring stretching at $1558 \mathrm{~cm}^{-1}$ and $\mathrm{CH}_{2}$ bending at $1455 \mathrm{~cm}^{-1}$.

The diclofenac infrared spectrum also presents bands at 1575 and $1400 \mathrm{~cm}^{-1}$, assigned to antisymmetric and symmetrical stretching of carboxylate group, respectively. The observed wavenumber variation $\Delta v\left(\mathrm{COO}^{-}\right)$of $175 \mathrm{~cm}^{-1}$ is characteristic of the drug in ionic form (Kovala-Demertzi et al., 1993). Therefore, both bands were detected at 1580 1584 $\mathrm{cm}^{-1}$ and $1378 \sim 1370 \mathrm{~cm}^{-1}$ for all organobentonite/drug solid samples, suggesting that $-\mathrm{COO}^{-}$groups were also involved, possibly through electrostatic interaction (Sun et al., 2017b, 2017c).

The occurrence of electrostatic interactions between diclofenac and Bent- $\mathrm{C}_{12}-100 \%$, Bent- $\mathrm{C}_{16}-100 \%$ and Bent- $\mathrm{C}_{12}-200 \%$ is not probable due to the negative charges of the surfaces at $\mathrm{pH}$ 6.0. Similar behavior was observed for an organophilic montmorillonite obtained using a concentration of $\mathrm{C}_{16} \mathrm{pyCl}$ at $92 \%$ of the $\mathrm{CEC}$ (Luo et al., 2017). Although the surface was negatively charged and the amount was lower than the $\mathrm{CEC}, \mathrm{ReO}_{4}{ }^{-}$was adsorbed. The proposed interaction was associated with the desorption of the surfactant weakly bound to montmorillonite, capturing of anions in solution and subsequent adsorption of $\mathrm{C}_{16} \mathrm{py}^{+} \mathrm{ReO}_{4}{ }^{-}$ on the external surface by hydrophobic interactions. This same mechanism was also suggested for the adsorption of $\mathrm{ClO}_{4}{ }^{-}$anions on $\mathrm{C}_{16} \mathrm{py}^{+}$.montmorillonite (Luo et al., 2016).

Finally, region 3 of the FTIR spectrum for free diclofenac presented bands at 766, 746 and $714 \mathrm{~cm}^{-1}$ assigned to $\mathrm{C}-\mathrm{H}$ deformation (Kovala-Demertzi et al., 1993) and characteristic of 1,2-disubstituted and 1,2,3-trisubstituted aromatic rings (Iliescu et al., 2004), and the band at $635 \mathrm{~cm}^{-1}$ is characteristic of ring deformation modes (Lin-Vien et al., 1991). For this region, only Bent- $\mathrm{C}_{16}-200 \%$ exhibited a shoulder at $746 \mathrm{~cm}^{-1}$ when a high initial drug concentration was used. 


\subsubsection{Mechanism of drug interaction}

487

488

489

490

491

492

493

494

495

496

497

498

499

500

501

502

503

504

505

506

507

508

509

The new properties of the organophilic clays were attributed to a change in character from hydrophilic to hydrophobic, anion exchange as a consequence of the incorporation of excess surfactant and different packing densities and arrangements of the organic cations in the interlayer region, which favor interactions with pollutants (Oliveira et al., 2017; Oliveira and Guégan, 2016). Thus, the different characteristics presented by each solid contributed in several forms to diclofenac adsorption due to the different affinities, as observed in the values of $\mathrm{q}_{\max }$

A theoretical study realized by Meleshyn and Bunnenberg (2006) indicated that interlayer anion sorption on montmorillonite modified with $\mathrm{C}_{16} \mathrm{pyCl}$ occurs only for higher surfactant contents and basal spacings $(2.1 \sim 2.2 \mathrm{~nm})$ and consequently when a pseudotrimolecular form is obtained. In this condition, chloride can be accommodated between the layers as a counter ion of $\mathrm{C}_{16} \mathrm{py}^{+}$or sodium cations. Several works have shown that some of the interlayer cations of pristine bentonite remain in the bentonite structure even when the amount of $\mathrm{C}_{16} \mathrm{py}^{+}$incorporated is equal to or higher than the $\mathrm{CEC}$ and act as cation or anion exchange sites (Chitrakar et al., 2012; Luo et al., 2016), in agreement with the theoretical study (Meleshyn and Bunnenberg, 2006).

Based on the $\mathrm{CHNCl}$ results, the amount of surfactant higher than the $\mathrm{CEC}$ and the presence of chloride ions $\left(0.154 \mathrm{mmol} \mathrm{g}^{-1}\right)$ were observed only for Bent- $\mathrm{C}_{16} \mathrm{py}-200 \%$. In this case, $0.145 \mathrm{mmol} \mathrm{g}^{-1} \mathrm{Cl}^{-}$was detected in the equilibrium solution after diclofenac adsorption, which was half of the maximum diclofenac adsorbed $\left(0.291 \mathrm{mmol} \mathrm{g}^{-1}\right)$.

For the other solids, although the amount of alkylpyridinium cation incorporated was lower than the CEC of the pristine bentonite, the FTIR results also suggested electrostatic between the incorporated surfactant (pyridinium) and the carboxylate groups of diclofenac. 

contributes to organophilic (alkyl groups of the salt and ring of the drug) and $\pi$ - $\pi$ interactions,

512 the latter between the pyridine rings and the aromatic rings of the pollutant. In particular,

513 interactions involving $\pi$ electrons have often been described in the adsorption of aromatic 514 compounds by pyridinium organophilic clays (Changchaivong and Khaodhiar, 2009; Gu et 515 al., 2014; Luo et al., 2015; Yang et al., 2016), and for diclofenac adsorption by benzyldimethyltetradecylammonium-montmorillonite (Oliveira et al., 2017; Oliveira and

517 Guégan, 2016). A general scheme of the proposed interaction mechanisms of drug adsorption on organobentonites was based on obtained results and also in the literature. Depending of the 519 sample, at least four different contributions were involved in the diclofenac adsorption as $520 \quad$ illustrated in Figure 4.

\section{Conclusion}

The organic modification of bentonite with alkylpyridinium cations through microwave heating resulted in organophilic clays with different characteristics, which were dependent on the amount of surfactant and the size of the organic chain, as shown in the CHN and XRD results. The use of microwave for organophilization of bentonites with both surfactants at time of 5 min at $50{ }^{\circ} \mathrm{C}$ was a promising technique.

As a consequence, the organobentonites exhibited different diclofenac adsorption 528 capacity from aqueous solution, which were probably influenced by the amount of 529 incorporated surfactant, the packing density and different arrangements of the organic 530 moieties in the interlayer region. The differences between these factors determine the degree 531 of affinity of the hybrids for the anionic drug on the surface due to the different adsorption 532 sites. 

$\pi-\pi$ interactions for all functionalized bentonites. The best performance for diclofenac adsorption was $91.13 \mathrm{mg} \mathrm{g}^{-1}$ for Bent- $\mathrm{C}_{16}$ py-200\% due to the excess of surfactant incorporated. This present study demonstrated the versatility of these solids for anionic species or even neutral species, considering the presence of different interaction sites.

Acknowledgement

$\mathrm{CNPq}$ is acknowledged for financial support in the form of research fellowships

spectroscopy.

\section{References}

Abbate, C., Ambrosoli, R., Minati, J.L., Gennari, M., Arena, M., 2013. Metabolic and molecular methods to evaluate the organoclay effects on a bacterial community. Environ. Pollut. 179, 39-44. https://doi.org/10.1016/j.envpol.2013.04.012

Acuña, V., Ginebreda, A., Mor, J.R., Petrovic, M., Sabater, S., Sumpter, J., Barceló, D., 2015. Balancing the health benefits and environmental risks of pharmaceuticals: Diclofenac as an example. Environ. Int. 85, 327-333. https://doi.org/10.1016/j.envint.2015.09.023

Andrew Lin, K.-Y., Yang, H., Lee, W.-D., 2015. Enhanced removal of diclofenac from water using a zeolitic imidazole framework functionalized with cetyltrimethylammonium bromide (CTAB). RSC Adv. 5, 81330-81340. https://doi.org/10.1039/C5RA08189K

Beltrán, F.J., Pocostales, P., Alvarez, P., Oropesa, A., 2009. Diclofenac removal from water with ozone and activated carbon. J. Hazard. Mater. 163, 768-776. https://doi.org/10.1016/J.JHAZMAT.2008.07.033

Biel-Maeso, M., Baena-Nogueras, R.M., Corada-Fernández, C., Lara-Martín, P.A., 2018. Occurrence, distribution and environmental risk of pharmaceutically active compounds (PhACs) in coastal and ocean waters from the Gulf of Cadiz (SW Spain). Sci. Total Environ. 612, 649-659. https://doi.org/10.1016/J.SCITOTENV.2017.08.279

Biswas, B., Warr, L.N., Hilder, E.F., Goswami, N., Rahman, M.M., Churchman, J.G., Vasilev, K., Pan, G., Naidu, R., 2019. Biocompatible functionalisation of nanoclays for improved environmental remediation. Chem. Soc. Rev. 48, 3740-3770. https://doi.org/10.1039/C8CS01019F 
Bonnefille, B., Gomez, E., Courant, F., Escande, A., Fenet, H., 2018. Diclofenac in the marine environment: A review of its occurrence and effects. Mar. Pollut. Bull. 131, 496506. https://doi.org/10.1016/j.marpolbul.2018.04.053

Brito, D.F., Silva Filho, E.C., Fonseca, M.G., Jaber, M., 2018. Organophilic bentonites obtained by microwave heating as adsorbents for anionic dyes. J. Environ. Chem. Eng. 6, 7080-7090. https://doi.org/10.1016/j.jece.2018.11.006

Carballa, M., Omil, F., Lema, J.M., 2005. Removal of cosmetic ingredients and pharmaceuticals in sewage primary treatment. Water Res. 39, 4790-4796. https://doi.org/10.1016/J.WATRES.2005.09.018

Cavalcanti, G.R.S., Fonseca, M.G., da Silva Filho, E.C., Jaber, M., 2019. Thiabendazole/bentonites hybrids as controlled release systems. Colloids Surfaces B Biointerfaces 176, 249-255. https://doi.org/10.1016/j.colsurfb.2018.12.030

Changchaivong, S., Khaodhiar, S., 2009. Adsorption of naphthalene and phenanthrene on dodecylpyridinium-modified bentonite. Appl. Clay Sci. 43, 317-321. https://doi.org/10.1016/j.clay.2008.09.012

Chen, B., Zhu, L., Zhu, J., Xing, B., 2005. Configurations of the bentonite-sorbed myristylpyridinium cation and their influences on the uptake of organic compounds. Environ. Sci. Technol. 39, 6093-6100. https://doi.org/10.1021/es0502674

Chien, S.H., Clayton, W.R., 1984. Application of Elovich equation to the kinetics of phosphate release and sorption in soils ${ }^{1}$. Soil Sci. Soc. Am. J. 44, 265-268. https://doi.org/10.2136/sssaj1980.03615995004400020013x

Chitrakar, R., Makita, Y., Hirotsu, T., Sonoda, A., 2012. Montmorillonite modified with hexadecylpyridinium chloride as highly efficient anion exchanger for perchlorate ion. Chem. Eng. J. 191, 141-146. https://doi.org/10.1016/j.cej.2012.02.085

França, D.B., Torres, S.M., Filho, E.C.S., Fonseca, M.G., Jaber, M., 2019. Understanding the interactions between ranitidine and magadiite: Influence of the interlayer cation. Chemosphere 222, 980-990. https://doi.org/10.1016/j.chemosphere.2019.01.154

Freundlich, H.M.F., 1906. Over the adsorption in solution. J. Phys. Chem. 57, 385-471.

Ghemit, R., Makhloufi, A., Djebri, N., Flilissa, A., Zerroual, L., Boutahala, M., 2019. Adsorptive removal of diclofenac and ibuprofen from aqueous solution by organobentonites: Study in single and binary systems. Groundw. Sustain. Dev. 8, 520529. https://doi.org/10.1016/J.GSD.2019.02.004

Greenland, D.J., Quirk, J.P., 1962. Adsorption of 1-n-alkyl pyridinium bromides by montmorillonite. Clays Clay Miner. 9, 484-499.

Gu, Z., Gao, M., Luo, Z., Lu, L., Ye, Y., Liu, Y., 2014. Bis-pyridinium dibromides modified organo-bentonite for the removal of aniline from wastewater : A positive role of $\pi-\pi$ polar interaction. Appl. Surf. Sci. 290, 107-115. https://doi.org/10.1016/j.apsusc.2013.11.008

He, B., Wang, J., Liu, J., Hu, X., 2017. Eco-pharmacovigilance of non-steroidal antiinflammatory drugs: Necessity and opportunities. Chemosphere 181, 178-189. https://doi.org/10.1016/J.CHEMOSPHERE.2017.04.084 
He, H., Ma, L., Zhu, J., Frost, R.L., Theng, B.K.G., Bergaya, F., 2014. Synthesis of organoclays: A critical review and some unresolved issues. Appl. Clay Sci. 100, 22-28. https://doi.org/10.1016/j.clay.2014.02.008

Herrera, P., Burghardt, R., Huebner, H.J., Phillips, T.D., 2004. The efficacy of sandimmobilized organoclays as filtration bed materials for bacteria. Food Microbiol. 21, 110. https://doi.org/10.1016/S0740-0020(03)00050-9

Herrera, P., Burghardt, R.C., Phillips, T.D., 2000. Adsorption of Salmonella enteritidis by cetylpyridinium-exchanged montmorillonite clays. Vet. Microbiol. 74, 259-272. https://doi.org/10.1016/S0378-1135(00)00157-7

Ho, Y.S., McKay, G., 1999. Pseudo-second order model for sorption processes. Process Biochem. 34, 451-465. https://doi.org/10.1016/S0032-9592(98)00112-5

Iliescu, T., Baia, M., Kiefer, W., 2004. FT-Raman, surface-enhanced Raman spectroscopy and theoretical investigations of diclofenac sodium. Chem. Phys. 298, 167-174. https://doi.org/10.1016/J.CHEMPHYS.2003.11.018

Jović-Jovičić, N., Mojović, M., Stanković, D., Nedić-Vasiljević, B., Milutinović-Nikolić, A., Banković, P., Mojović, Z., 2019. Characterization and electrochemical properties of organomodified and corresponding derived carbonized clay. Electrochim. Acta 296, 387-396. https://doi.org/10.1016/J.ELECTACTA.2018.11.031

Karaman, R., Khamis, M., Quried, M., Halabieh, R., Makharzeh, I., Manassra, A., Abbadi, J., Qtait, A., Bufod, S.A., Nasser, A., Nir, S., 2012. Removal of diclofenac potassium from wastewater using clay-micelle complex. Environ. Technol. 33, 1279-1287. https://doi.org/10.1080/09593330.2011.619582

Ke, Y.L., Jiao, L.F., Song, Z.H., Xiao, K., Lai, T.M., Lu, J.J., Hu, C.H., 2014. Effects of cetylpyridinium-montmorillonite, as alternative to antibiotic, on the growth performance, intestinal microflora and mucosal architecture of weaned pigs. Anim. Feed Sci. Technol. 198, 257-262. https://doi.org/10.1016/j.anifeedsci.2014.10.010

Klaudia, Ś., Szaniawska, A., Caban, M., 2019. Evaluation of bioconcentration and metabolism of diclofenac in mussels Mytilus trossulus - laboratory study. Mar. Pollut. Bull. J. 141, 249-255. https://doi.org/10.1016/j.marpolbul.2019.02.050

Kovala-Demertzi, D., Dimitris, M., Terzis, A., 1993. Metal complexes of the antiinflammatory drug sodium [2-[(2, 6-dichlorophenyl) amino] phenyl] acetate (diclofenac sodium). Molecular and crystal structure of cadmium diclofenac. Polyhedron 12, 13611370. https://doi.org/org/10.1016/S0277-5387(00)84327-2

Lagaly, G., Ogawa, M., Dékány, I., 2013. Clay mineral-organic interactions, in: Bergaya, F., Lagaly, G. (Eds.), Handbook of Clay Science. Elsevier, Developments in Clay Science, Amsterdam, p. 435-505 (Chapter 10.3). https://doi.org/10.1016/B978-0-08-0982588.00015-8

Lagergren, S., 1898. Zur theorie der sogenannten adsorption geloster kungliga svenska vetenskapsakdemiens. Handlingar 24, 1-39.

Langmuir, I., 1918. The adsorption of gases on plane surfaces of glass mica and platinum. J. Am. Chem. Soc. 40, 1361-1403. https://doi.org/10.1021/ja02242a004 
Li, J., Zhu, L., Cai, W., 2006. Characteristics of organobentonite prepared by microwave as a sorbent to organic contaminants in water. Colloids Surfaces A Physicochem. Eng. Asp. 281, 177-183. https://doi.org/10.1016/j.colsurfa.2006.02.055

Lima, É.C., Adebayo, M.A., Machado, F.M., 2015. Kinetic and Equilibrium Models of Adsorption, in: Bergmann, C.P., Machado, F.M. (Eds.), Carbon Nanomaterials as Adsorbents for Environmental and Biological Applications. Springer, Cham, pp. 33-69. https://doi.org/10.1007/978-3-319-18875-1_3

Lin-Vien, D., Colthup, N.B., Fateley, W.G., Grasselli, J.G., 1991. The Handbook of infrared and raman characteristic frequencies of organic molecules, first. ed. Academic Press.

Lonappan, L., Kaur, S., Kumar, R., Verma, M., Surampalli, R.Y., 2016. Diclofenac and its transformation products : Environmental occurrence and toxicity - A review. Environ. Int. 96, 127-138. https://doi.org/10.1016/j.envint.2016.09.014

Luo, W., Hirajima, T., Sasaki, K., 2016. Optimization of hexadecylpyridinium-modified montmorillonite for removal of perchlorate based on adsorption mechanisms. Appl. Clay Sci. 123, 29-36. https://doi.org/10.1016/j.clay.2016.01.005

Luo, W., Inoue, A., Hirajima, T., Sasaki, K., 2017. Synergistic effect of $\mathrm{Sr}^{2+}$ and $\mathrm{ReO}_{4}$ adsorption on hexadecyl pyridinium-modified montmorillonite. Appl. Surf. Sci. 394, 431-439. https://doi.org/10.1016/j.apsusc.2016.10.135

Luo, W., Sasaki, K., Hirajima, T., 2018. Influence of the pre-dispersion of montmorillonite on organic modification and the adsorption of perchlorate and methyl red anions. Appl. Clay Sci. 154, 1-9. https://doi.org/10.1016/j.clay.2017.12.032

Luo, Z., Gao, M., Yang, S., Yang, Q., 2015. Adsorption of phenols on reduced-charge montmorillonites modified by bispyridinium dibromides: Mechanism, kinetics and thermodynamics studies. Colloids Surfaces A Physicochem. Eng. Asp. 482, 222-230. https://doi.org/10.1016/j.colsurfa.2015.05.014

Maia, G.S., Andrade, J.R., Silva, M.G.C., Vieira, M.G.A., 2019. Adsorption of diclofenac sodium onto commercial organoclay: Kinetic, equilibrium and thermodynamic study. Powder Technol. 345, 140-150. https://doi.org/10.1016/j.powtec.2018.12.097

Malachová, K., Praus, P., Pavlíčková, Z., Turicová, M., 2009. Activity of antibacterial compounds immobilised on montmorillonite. Appl. Clay Sci. 43, 364-368. https://doi.org/10.1016/J.CLAY.2008.11.003

Martinez-Costa, J.I., Leyva-Ramos, R., Padilla-Ortega, E., 2018. Sorption of diclofenac from aqueous solution on an organobentonite and adsorption of cadmium on organobentonite saturated with diclofenac. Clays Clay Miner. 66, 515-528. https://doi.org/10.1346/ccmn.2018.064119

Meleshyn, A., Bunnenberg, C., 2006. Interlayer expansion and mechanisms of anion sorption of Na-montmorillonite modified by cetylpyridinium chloride: A Monte Carlo study. J. Phys. Chem. B 110, 2271-2277. https://doi.org/10.1021/jp056178v

Momina, Shahadat, M., Isamil, S., 2018. Regeneration performance of clay-based adsorbents for the removal of industrial dyes: A review. RSC Adv. 8, 24571-24587. https://doi.org/10.1039/c8ra04290j 
Moreno-González, R., Rodríguez-Mozaz, S., Huerta, B., Barceló, D., León, V.M., 2016. Do pharmaceuticals bioaccumulate in marine molluscs and fish from a coastal lagoon? Environ. Res. 146, 282-298. https://doi.org/10.1016/J.ENVRES.2016.01.001

Mugunthan, E., Saidutta, M.B., Jagadeeshbabu, P.E., 2018. Visible light assisted photocatalytic degradation of diclofenac using $\mathrm{TiO}_{2}-\mathrm{WO}_{3}$ mixed oxide catalysts. Environ. Nanotechnology, Monit. Manag. 10, 322-330. https://doi.org/10.1016/J.ENMM.2018.07.012

Muñoz-Shugulí, C., Rodríguez, F.J., Bruna, J.E., Galotto, M.J., Sarantópoulos, C., Favaro Perez, M.A., Padula, M., 2019. Cetylpyridinium bromide-modified montmorillonite as filler in low density polyethylene nanocomposite films. Appl. Clay Sci. 168, 203-210. https://doi.org/10.1016/j.clay.2018.10.020

Oaks, J.L., Gilbert, M., Virani, M.Z., Watson, R.T., Meteyer, C.U., Rideout, B.A., Shivaprasad, H.L., Ahmed, S., Iqbal Chaudhry, M.J., Arshad, M., Mahmood, S., Ali, A., Ahmed Khan, A., 2004. Diclofenac residues as the cause of vulture population decline in Pakistan. Nature 427, 630-633. https://doi.org/10.1038/nature02317

Oliveira, T. De, Guégan, R., Thiebault, T., Le, C., Muller, F., Teixeira, V., Giovanela, M., Boussafir, M., 2017. Adsorption of diclofenac onto organoclays: Effects of surfactant and environmental ( $\mathrm{pH}$ and temperature) conditions. J. Hazard. Mater. 323, 558-566. https://doi.org/10.1016/j.jhazmat.2016.05.001

Oliveira, T., Guégan, R., 2016. Coupled organoclay/micelle action for the adsorption of diclofenac. Environ. Sci. Technol. 50, 10209-10215. https://doi.org/10.1021/acs.est.6b03393

Özdemir, G., Yapar, S., Limoncu, M.H., 2013. Preparation of cetylpyridinium montmorillonite for antibacterial applications. Appl. Clay Sci. 72, 201-205. https://doi.org/10.1016/j.clay.2013.01.010

Pérez-Estrada, L.A., Malato, S., Gernjak, W., Agüera, A., Thurman, E.M., Ferrer, I., Fernández-Alba, A.R., 2005. Photo-fenton degradation of diclofenac: Identification of main intermediates and degradation pathway. Environ. Sci. Technol. 39, 8300-8306. https://doi.org/10.1021/ES050794N

Queiroga, L.N.F., Pereira, M.B.B., Silva, L.S., Silva Filho, E.C., Santos, I.M.G., Fonseca, M.G., Georgelin, T., Jaber, M., 2019. Microwave bentonite silylation for dye removal: Influence of the solvent. Appl. Clay Sci. 168, 478-487. https://doi.org/10.1016/j.clay.2018.11.027

Sarkar, B., Megharaj, M., Shanmuganathan, D., Naidu, R., 2013. Toxicity of organoclays to microbial processes and earthworm survival in soils. J. Hazard. Mater. 261, 793-800. https://doi.org/10.1016/J.JHAZMAT.2012.11.061

Schampera, B., Dultz, S., 2009. Determination of diffusive transport in HDPymontmorillonite by $\mathrm{H}_{2} \mathrm{O}-\mathrm{D}_{2} \mathrm{O}$ exchange using in situ ATR-FTIR spectroscopy. Clay Miner. 44, 249-266. https://doi.org/10.1180/claymin.2009.044.2.249

Scheurell, M., Franke, S., Shah, R.M., Hühnerfuss, H., 2009. Occurrence of diclofenac and its metabolites in surface water and effluent samples from Karachi, Pakistan. Chemosphere 77, 870-876. https://doi.org/10.1016/J.CHEMOSPHERE.2009.07.066 
Skoog, D.A., West, D.M., Holler, F.J., Crouch, S.R., 2012. Fundamentals of analytical chemistry.

Slaný, M., Jankovič, L', Madejová, J., 2019. Structural characterization of organomontmorillonites prepared from a series of primary alkylamines salts: Mid-IR and nearIR study. Appl. Clay Sci. 176, 11-20. https://doi.org/10.1016/j.clay.2019.04.016

Starling, M.C.V.M., Amorim, C.C., Leão, M.M.D., 2019. Occurrence, control and fate of contaminants of emerging concern in environmental compartments in Brazil. J. Hazard. Mater. 372, 17-36. https://doi.org/10.1016/J.JHAZMAT.2018.04.043

Sun, K., Shi, Y., Chen, H., Wang, X., Li, Z., 2017a. Extending surfactant-modified 2:1 clay minerals for the uptake and removal of diclofenac from water. J. Hazard. Mater. 323, 567-574. https://doi.org/10.1016/j.jhazmat.2016.05.038

Sun, K., Shi, Y., Wang, X., Li, Z., 2017b. Sorption and retention of diclofenac on zeolite in the presence of cationic surfactant. J. Hazard. Mater. 323, 584-592. https://doi.org/10.1016/j.jhazmat.2016.08.026

Sun, K., Shi, Y., Wang, X., Rasmussen, J., Li, Z., Zhu, J., 2017c. Organokaolin for the uptake of pharmaceuticals diclofenac and chloramphenicol from water. Chem. Eng. J. 330, 1128-1136. https://doi.org/10.1016/j.cej.2017.08.057

Temkin, M.J., Pyzhev, V., 1940. Recent modifications to Langmuir isotherms. Acta Physicochim. USSR 12, 217-222.

Teppen, B.J., Aggarwal, V., 2007. Thermodynamics of organic cation exchange selectivity in smectites. Clays Clay Miner. 55, 119-130. https://doi.org/10.1346/CCMN.2007.0550201

Thanhmingliana, D.T., 2015. Efficient use of hybrid materials in the remediation of aquatic environment contaminated with micro-pollutant diclofenac sodium. Chem. Eng. J. 263, 364-373. https://doi.org/10.1016/j.cej.2014.10.102

Vieno, N., Sillanpää, M., 2014. Fate of diclofenac in municipal wastewater treatment plant A review. Environ. Int. 69, 28-39. https://doi.org/10.1016/J.ENVINT.2014.03.021

Volzone, C., Rinaldi, J.O., Ortiga, J., 2002. $\mathrm{N}_{2}$ and $\mathrm{CO}_{2}$ Adsorption by TMA-and HDPMontmorillonites. Mater. Res. 5, 475-479. https://doi.org/10.1590/S151614392002000400013

Witthuhn, B., Klauth, P., Klumpp, E., Narres, H.D., Martinius, H., 2005. Sorption and biodegradation of 2,4-dichlorophenol in the presence of organoclays. Appl. Clay Sci. 28, 55-66. https://doi.org/10.1016/j.clay.2004.01.003

Yang, Q., Gao, M., Luo, Z., Yang, S., 2016. Enhanced removal of bisphenol A from aqueous solution by organo-montmorillonites modified with novel Gemini pyridinium surfactants containing long alkyl chain. Chem. Eng. J. 285, 27-38. https://doi.org/10.1016/j.cej.2015.09.114

Yapar, S., 2009. Physicochemical study of microwave-synthesized organoclays. Colloids Surfaces A Physicochem. Eng. Asp. 345, 75-81. https://doi.org/10.1016/j.colsurfa.2009.04.032

Zhu, L., Tian, S., Shi, Y., 2005. Adsorption of volatile organic compounds onto porous clay 
779

780

781

782

783

784

785

786

787

788

789

790

791

792

793

794 heterostructures based on spent organobentonites. Clays Clay Miner. 53, 123-136.

https://doi.org/10.1346/CCMN.2005.0530202

Zhuang, G., Zhang, Z., Jaber, M., 2019. Organoclays used as colloidal and rheological additives in oil-based drilling fluids: An overview. Appl. Clay Sci. 177, 63-81. https://doi.org/10.1016/J.CLAY.2019.05.006

Zhuang, G., Zhang, Z., Peng, S., Gao, J., Jaber, M., 2018. Enhancing the rheological properties and thermal stability of oil-based drilling fluids by synergetic use of organomontmorillonite and organo-sepiolite. Appl. Clay Sci. 161, 505-512. https://doi.org/10.1016/J.CLAY.2018.05.018

1

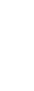

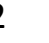

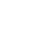


795 Figure 2 - XRD patterns of organobentonites for (i) Bent- $\mathrm{C}_{12}$ py-100\%, (ii) Bent- $\mathrm{C}_{16} \mathrm{py}-100 \%$, 796 (iii) Bent- $\mathrm{C}_{12}$ py-200\% and (iv) Bent- $\mathrm{C}_{16}$ py-200\% (a) before and after diclofenac adsorption 797 for hybrids prepared with initial drug concentrations of (b) $10 \mathrm{mg} \mathrm{L}^{-1}$, (c) $100 \mathrm{mg} \mathrm{L}^{-1}$ and (d) $798 \quad 500 \mathrm{mg} \mathrm{L}^{-1}$.

799

800 Figure 3 - FTIR results for a) Bent- $\mathrm{C}_{16}$ py-200\% before and after diclofenac sorption using 801 initial concentrations of b) $10 \mathrm{mg} \mathrm{L}^{-1}$, c) $100 \mathrm{mg} \mathrm{L}^{-1}$ and d) $500 \mathrm{mg} \mathrm{L}^{-1}$; and e) free diclofenac 802 sodium.

803

804

Figure 4 - Proposed scheme for diclofenac/organobentonite interaction, $\mathrm{M}=$ mechanism.

805

806

807

808

809

810

811

812

813 

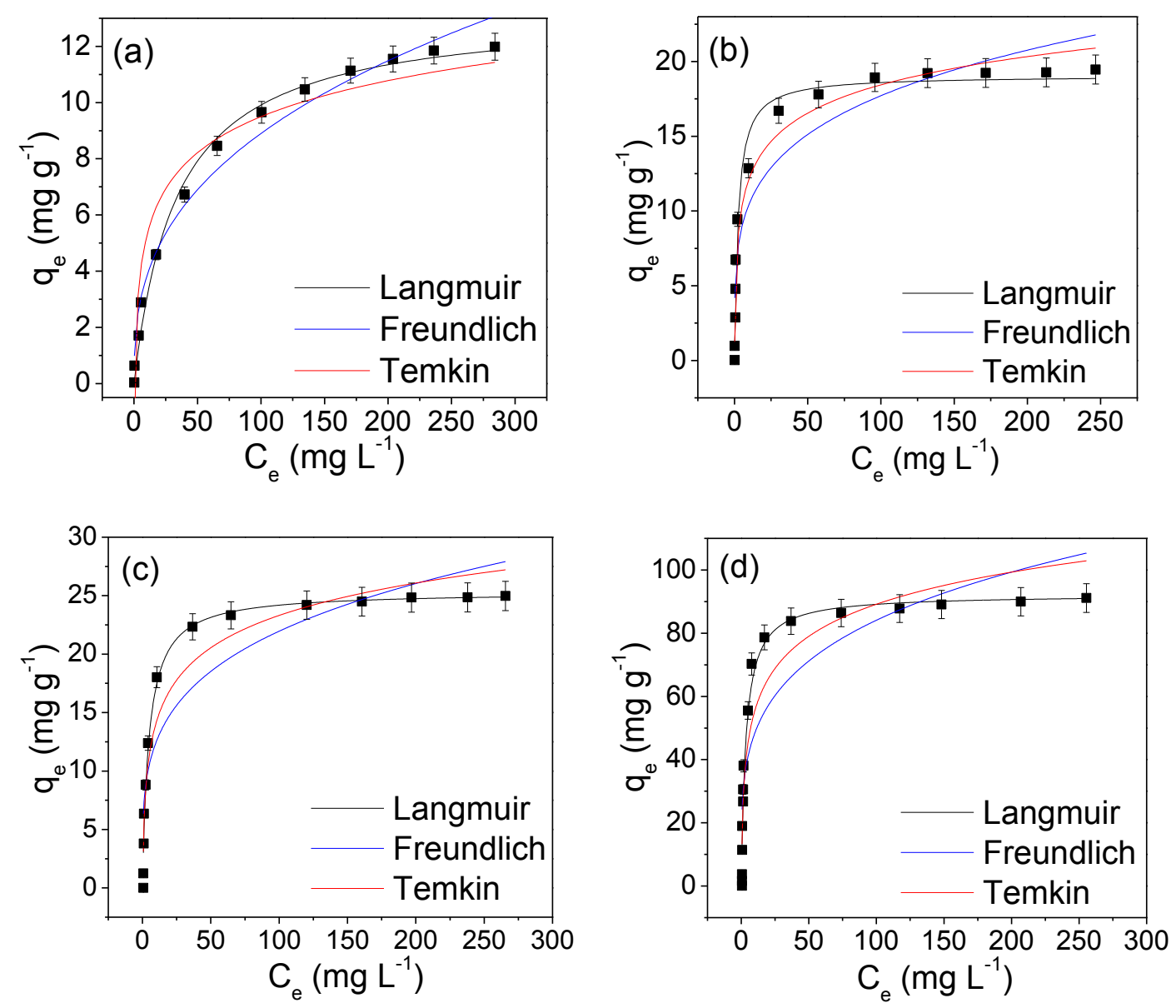

$814 \quad$ Figure 1

815

816

817

818

819

820

821

822 

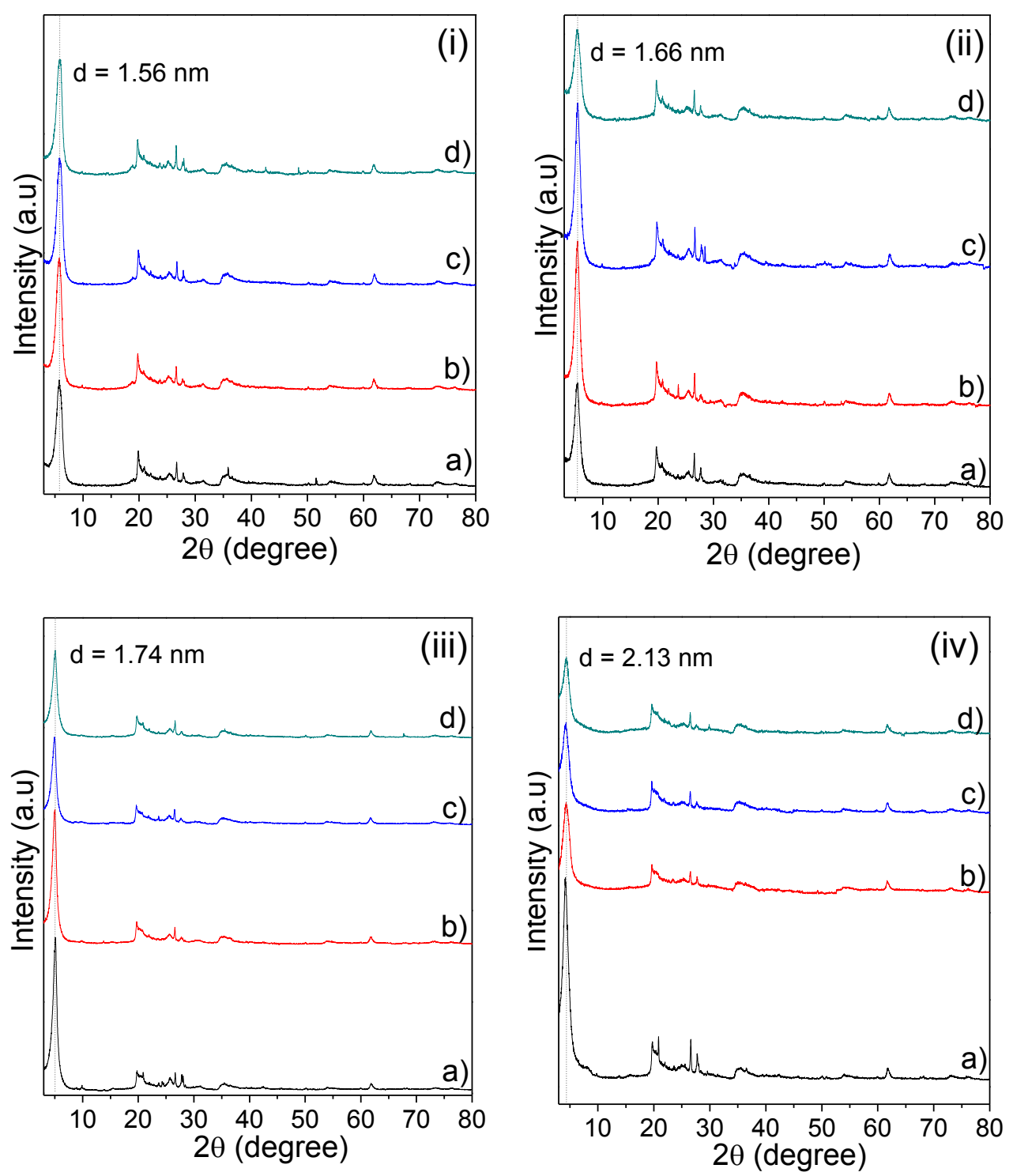

823

824

$825 \quad$ Figure 2

826

827

828

829

830 

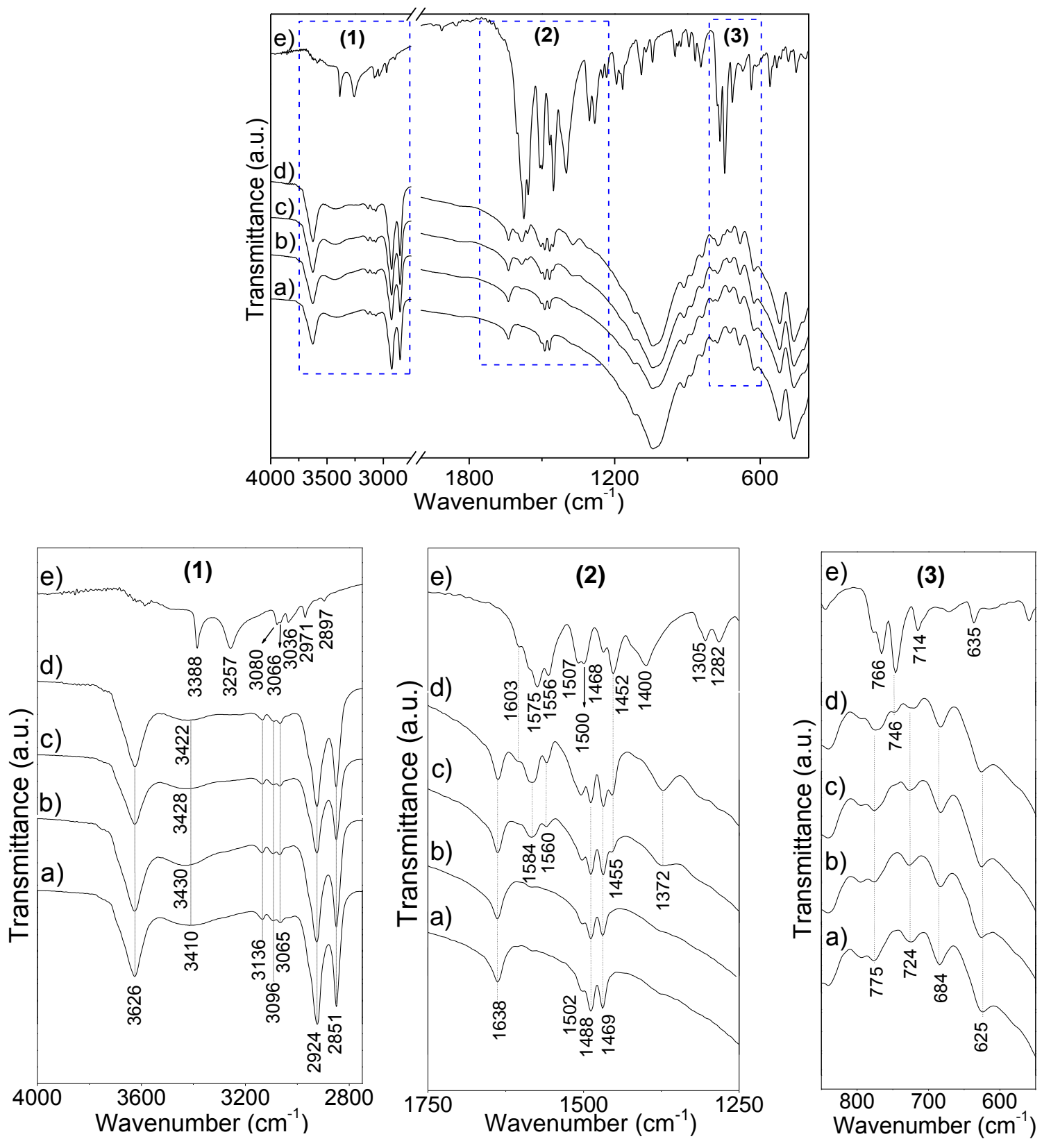

$832 \quad$ Figure 3

833

834

835 


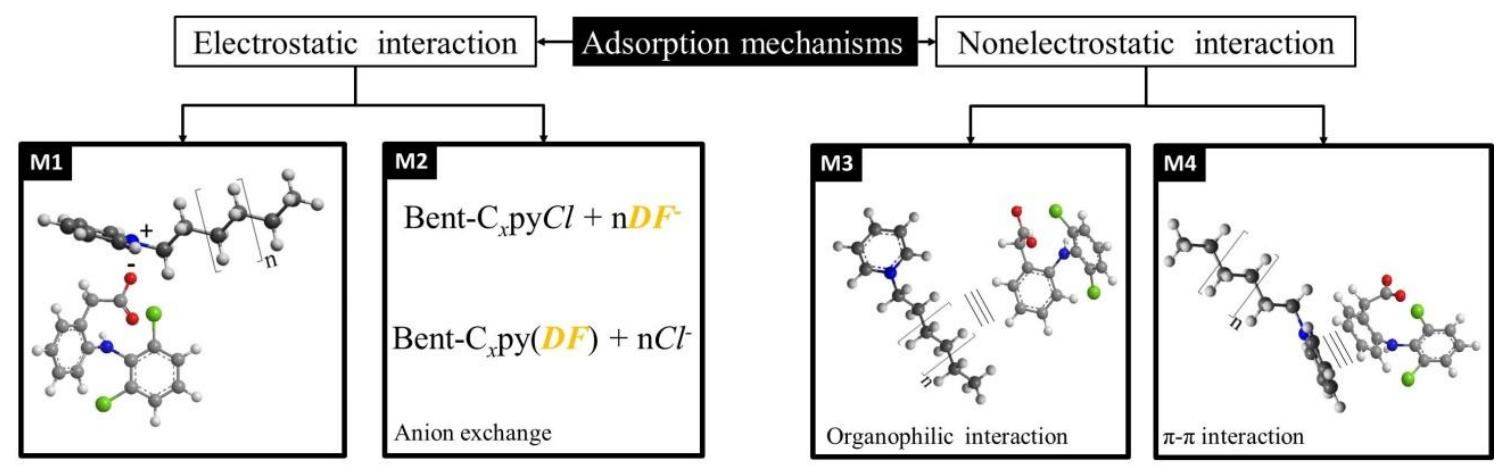

\section{Organobentonite/drug hybrids}

839

- $\bullet \mathrm{N} \bullet \mathrm{H} \bullet \mathrm{O} \odot \mathrm{Cl} \cap \mathrm{Na}$

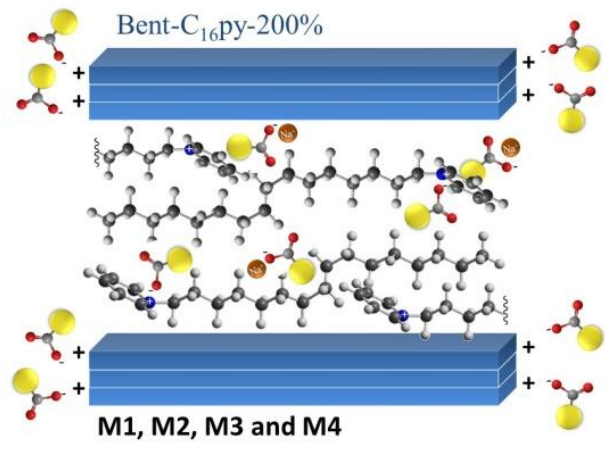

840

Figure 4

841 


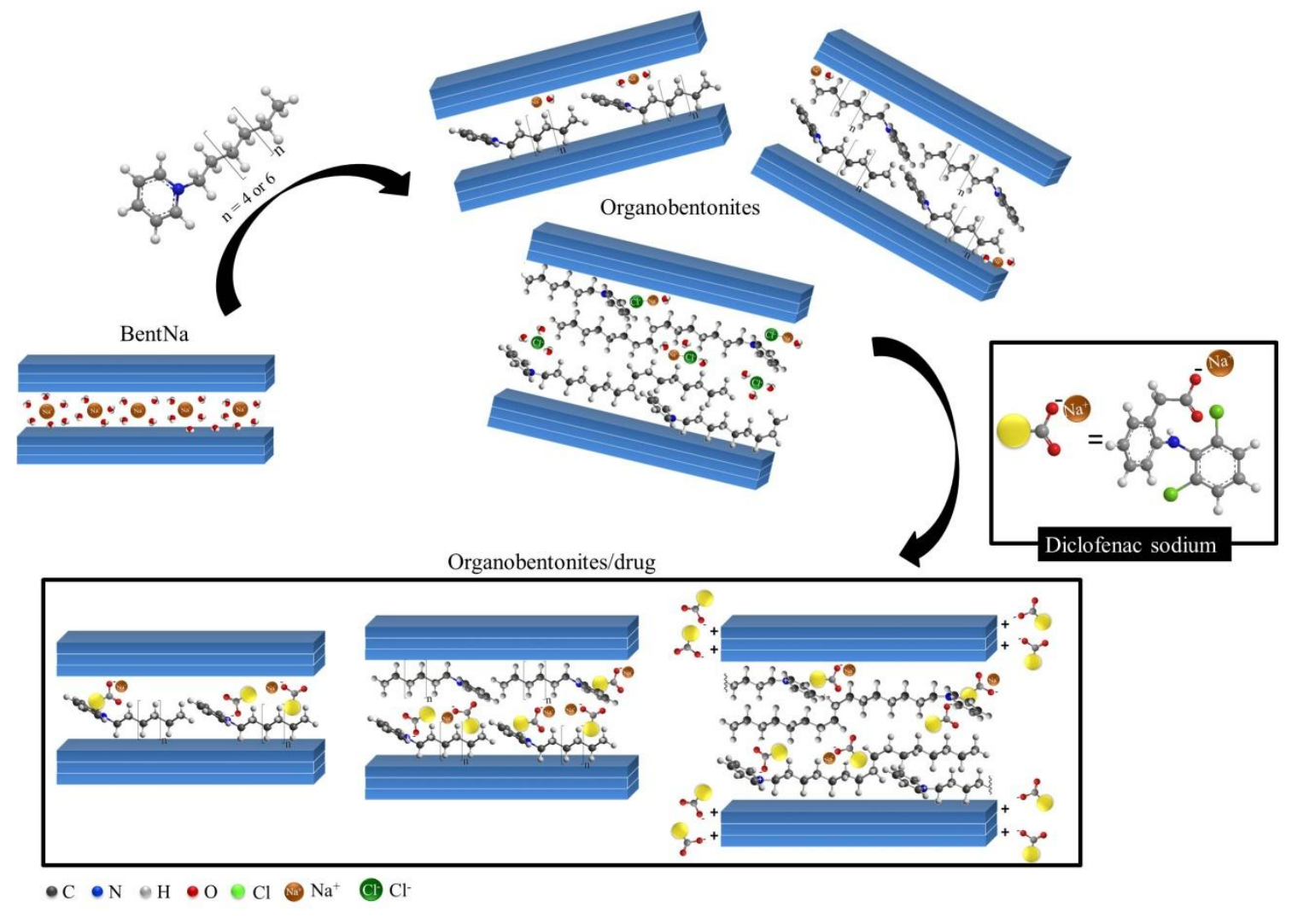


861 Table $1-\mathrm{C}, \mathrm{N}$ and $\mathrm{Cl}$ elemental analysis of organobentonites and percentage of incorporated 862 surfactant in relation to the CEC of BentNa $\left(\sigma_{f}\right)$.

863

\begin{tabular}{|c|c|c|c|c|c|c|}
\hline \multirow[t]{2}{*}{ Sample } & \multicolumn{2}{|c|}{$\mathrm{C}$} & \multicolumn{2}{|r|}{$\mathrm{N}$} & \multirow{2}{*}{$\begin{array}{c}\sigma_{f} \\
\%\end{array}$} & \multirow{2}{*}{$\begin{array}{c}\mathrm{Cl}^{-} \\
\mathrm{mmol} \mathrm{g}^{-1}\end{array}$} \\
\hline & $\%$ & $\mathrm{mmol} \mathrm{g}^{-1}$ & $\%$ & $\mathrm{mmol} \mathrm{g}^{-1}$ & & \\
\hline Bent- $\mathrm{C}_{12} \mathrm{py}-100 \%$ & 12.30 & 10.25 & 0.93 & 0.66 & 89.0 & $*$ \\
\hline Bent-C 16 py-100\% & 15.75 & 13.13 & 0.97 & 0.69 & 92.8 & $*$ \\
\hline Bent-C 12 py-200\% & 14.85 & 12.38 & 0.98 & 0.70 & 93.3 & $*$ \\
\hline Bent-C 16 py-200\% & 20.85 & 17.37 & 1.18 & 0.84 & 112.4 & $0.15 \pm 0.01$ \\
\hline
\end{tabular}

865

866

867

868

869

870

871

872

873

874

875

876

877

878

879

880 
Table 2 - Kinetic parameters obtained from the pseudo-first-order, pseudo-second-order and

882 Elovich equations in nonlinear fitting of diclofenac adsorption on organophilic bentonites

883 (Experimental conditions: $25^{\circ} \mathrm{C}, \mathrm{pH} 6.0$ and $100 \mathrm{mg} \mathrm{L}^{-1}$ diclofenac solution).

\begin{tabular}{|c|c|c|c|c|c|}
\hline \multicolumn{6}{|l|}{ Pseudo-first-order } \\
\hline Solid & $\begin{array}{c}\mathrm{q}_{\mathrm{e}(\exp )} \\
\left(\mathrm{mg} \mathrm{g}^{-1}\right)\end{array}$ & $\begin{array}{c}\mathrm{k}_{1} \\
\left(\min ^{-1}\right)\end{array}$ & $\begin{array}{c}\mathrm{q}_{\mathrm{e}(\mathrm{cal})} \\
\left(\mathrm{mg} \mathrm{g}^{-1}\right)\end{array}$ & $\mathrm{R}^{2}$ & $\begin{array}{c}\mathrm{SD} \\
\left(\mathrm{mg} \mathrm{g}^{-1}\right)\end{array}$ \\
\hline Bent- $\mathrm{C}_{12}$ py-100\% & $5.50 \pm 0.10$ & $2.84 \pm 0.65$ & $5.01 \pm 0.13$ & 0.9242 & 0.410 \\
\hline Bent- $C_{16}$ py-100\% & $8.98 \pm 0.27$ & $3.54 \pm 0.82$ & $8.36 \pm 0.20$ & 0.9573 & 0.554 \\
\hline Bent- $\mathrm{C}_{12}$ py-200\% & $12.98 \pm 0.05$ & $2.18 \pm 0.12$ & $12.80 \pm 0.09$ & 0.9938 & 0.293 \\
\hline Bent- $\mathrm{C}_{16}$ py-200\% & $38.71 \pm 0.04$ & $4.06 \pm 0.33$ & $38.53 \pm 0.27$ & 0.9950 & 0.814 \\
\hline \multicolumn{6}{|l|}{ Pseudo-second-order } \\
\hline Solid & $\begin{array}{c}\mathrm{q}_{\mathrm{e}(\exp )} \\
\left(\mathrm{mg} \mathrm{g}^{-1}\right)\end{array}$ & $\begin{array}{c}\mathrm{k}_{2} \\
\left(\mathrm{~g} \mathrm{mg}^{-1} \min ^{-1}\right)\end{array}$ & $\begin{array}{c}\mathrm{q}_{\mathrm{e}(\mathrm{cal})} \\
\left(\mathrm{mg} \mathrm{g}^{-1}\right)\end{array}$ & $\mathrm{R}^{2}$ & $\begin{array}{c}\mathrm{SD} \\
\left(\mathrm{mg} \mathrm{g}^{-1}\right)\end{array}$ \\
\hline Bent- $\mathrm{C}_{12}$ py-100\% & $5.50 \pm 0.10$ & $0.99 \pm 0.25$ & $5.18 \pm 0.11$ & 0.9641 & 0.282 \\
\hline Bent-C 16 py-100\% & $8.98 \pm 0.27$ & $0.81 \pm 0.25$ & $8.54 \pm 0.16$ & 0.9752 & 0.422 \\
\hline Bent- $\mathrm{C}_{12}$ py-200\% & $12.98 \pm 0.05$ & $0.35 \pm 0.01$ & $13.06 \pm 0.05$ & 0.9985 & 0.141 \\
\hline Bent-C ${ }_{16}$ py-200\% & $38.71 \pm 0.04$ & $0.33 \pm 0.02$ & $38.95 \pm 0.11$ & 0.9993 & 0.308 \\
\hline \multicolumn{6}{|l|}{ Elovich } \\
\hline Solid & \multicolumn{2}{|c|}{$\left(10^{6} \mathrm{mg} \mathrm{g}^{-1} \min ^{-1}\right)$} & $\begin{array}{c}\beta \\
\left(\mathrm{g} \mathrm{mg}^{-1}\right)\end{array}$ & $\mathrm{R}^{2}$ & $\begin{array}{c}\mathrm{SD} \\
\left(\mathrm{mg} \mathrm{g}^{-1}\right)\end{array}$ \\
\hline Bent-C ${ }_{12}$ py-100\% & \multicolumn{2}{|l|}{$1.07 \pm 0.66$} & $3.56 \pm 0.13$ & 0.9983 & 0.061 \\
\hline Bent- $\mathrm{C}_{16}$ py-100\% & \multicolumn{2}{|l|}{$44.5 \pm 33.4$} & $2.57 \pm 0.09$ & 0.9992 & 0.076 \\
\hline Bent- $\mathrm{C}_{12}$ py- $200 \%$ & \multicolumn{2}{|l|}{$84.97 \pm 377.04$} & $1.73 \pm 0.38$ & 0.9622 & 0.727 \\
\hline Bent- $\mathrm{C}_{16}$ py-200\% & \multicolumn{2}{|c|}{$9.4810^{15} \pm 133.7810^{15}$} & $1.40 \pm 0.37$ & 0.9915 & 1.061 \\
\hline
\end{tabular}


888 according to the Langmuir, Freundlich and Temkin models.

\begin{tabular}{|c|c|c|c|c|c|}
\hline Langmuir & & & & & \\
\hline Solid & $\begin{array}{c}\mathrm{q}_{\mathrm{e}(\exp )} \\
\left(\mathrm{mg} \mathrm{g}^{-1}\right)\end{array}$ & $\begin{array}{c}\mathrm{q}_{\max } \\
\left(\mathrm{mg} \mathrm{g}^{-1}\right)\end{array}$ & $\begin{array}{c}\mathrm{K}_{\mathrm{L}} \\
\left(10^{-1} \mathrm{~L} \mathrm{mg}^{-1}\right)\end{array}$ & $\mathrm{R}^{2}$ & $\begin{array}{c}\mathrm{SD} \\
\left(\mathrm{mg} \mathrm{g}^{-1}\right)\end{array}$ \\
\hline Bent- $_{12}$ py-100\% & $13.02 \pm 0.65$ & $13.26 \pm 0.35$ & $0.30 \pm 0.03$ & 0.9917 & 0.41 \\
\hline Bent- $\mathrm{C}_{16}$ py-100\% & $19.30 \pm 0.96$ & $19.05 \pm 0.43$ & $4.00 \pm 0.56$ & 0.9806 & 1.05 \\
\hline Bent- $\mathrm{C}_{12}$ py-200\% & $25.50 \pm 1.02$ & $25.33 \pm 0.53$ & $2.11 \pm 0.24$ & 0.9843 & 1.23 \\
\hline Bent- $\mathrm{C}_{16}$ py-200\% & $91.13 \pm 1.82$ & $92.20 \pm 2.68$ & $2.91 \pm 0.39$ & 0.9704 & 6.15 \\
\hline Freundlich & & & & & \\
\hline Solid & $\mathrm{n}$ & $\begin{array}{c}\mathrm{K}_{f} \\
\left(\mathrm{mg} \mathrm{g}^{-1}\right)\left(\mathrm{mg} \mathrm{L}^{-1}\right)^{-1 / n}\end{array}$ & $\mathrm{R}^{2}$ & & $\begin{array}{c}\mathrm{SD} \\
\left(\mathrm{mg} \mathrm{g}^{-1}\right)\end{array}$ \\
\hline Bent- $\mathrm{C}_{12}$ py-100\% & $2.71 \pm 0.21$ & $1.63 \pm 0.23$ & 0.9767 & & 0.70 \\
\hline Bent- $\mathrm{C}_{16}$ py-100\% & $4.37 \pm 0.60$ & $6.17 \pm 0.91$ & 0.8943 & & 2.47 \\
\hline Bent- $\mathrm{C}_{12}$ py-200\% & $4.10 \pm 0.65$ & $7.10 \pm 1.33$ & 0.8533 & & 3.76 \\
\hline Bent- $\mathrm{C}_{16}$ py-200\% & $4.16 \pm 0.67$ & $27.82 \pm 4.81$ & 0.7961 & & 16.14 \\
\hline Temkin & & & & & \\
\hline Solid & $\begin{array}{c}\mathrm{b}_{\mathrm{T}} \\
\left(10^{2} \mathrm{~J} \mathrm{~mol}^{-1}\right)\end{array}$ & $\begin{array}{c}\mathrm{A}_{\mathrm{T}} \\
\left(\mathrm{L} \mathrm{mg}^{-1}\right)\end{array}$ & $\mathrm{R}^{2}$ & & $\begin{array}{c}\mathrm{SD} \\
\left(\mathrm{mg} \mathrm{g}^{-1}\right)\end{array}$ \\
\hline Bent- $\mathrm{C}_{12}$ py- $100 \%$ & $13.61 \pm 1.02$ & $1.70 \pm 0.56$ & 0.9366 & & 1.31 \\
\hline Bent- $\mathrm{C}_{16}$ py $-100 \%$ & $9.22 \pm 0.40$ & $8.60 \pm 1.90$ & 0.9766 & & 1.16 \\
\hline Bent- $\mathrm{C}_{12}$ py-200\% & $6.20 \pm 0.40$ & $3.43 \pm 0.99$ & 0.9498 & & 2.20 \\
\hline Bent- $\mathrm{C}_{16}$ py-200\% & $1.70 \pm 0.13$ & $4.41 \pm 1.38$ & 0.9156 & & 10.38 \\
\hline
\end{tabular}

